\title{
広域化された新配電自動化システムによる 監視制御・運用体制
}

\section{1.はじめに}

配電系統は電力系統の末端に位置し, 高低圧の配電線, 柱上変圧器, 開閉器等から構成されている ${ }^{(1)}$ 。高圧配電線 は配電用変電所に接続されており, 大口の需要家は高圧配 電線（一次配電線）から電力供給されている。高圧配電線 には柱上変圧器が分散して設置されており, 一般の住宅や 商店等の小口の需要家は, 柱上変圧器の二次側に接続され た低圧配電線（二次配電線）から供給されている。我が国 の高圧配電線の公称電圧（線間電圧）は大部分が $6.6 \mathrm{kV}$ で，一部に $3.3 \mathrm{kV} ， 11.4 \mathrm{kV}$ 等があり, 超過密地区，大 規模ニュータウン等で $22 \mathrm{kV}$ または $33 \mathrm{kV}$ となっている。 低圧配電線では $100 \mathrm{~V}$ および $200 \mathrm{~V}$ となっており，ビル， 工場等の一部で $400 \mathrm{~V}$ となっている。

各電力会社は供給信頼度を向上させるために配電自動化 システムを随時導入し，停電時間の短縮，電力品質の向 上, 需要家対応の迅速化を進めている。配電自動化システ ムは，配電線に事故停電が発生した場合に，その事故発生 区域を特定し，電柱上にある自動開閉器をコンピュー夕制 御により遠隔操作することで，それ以外の健全区域に送電 するシステムである。

本取材にご協力いただいた四国電力株式会社（以下，四 電）では, 変配監視制御の拠点集中化を進めており, 配電 自動化システムの更新を 2000 年に松山支店， 2001 年に高 知支店， 2003 年に徳島支店，2004 年に高松支店の 4 県都 支店で完了しており，県都支店システムとして運用してい る。新システムは装置とその機能の高度化に加え, 従来の 営業所単位の監視制御から, 支店営業部と営業所を連係さ せた広域化（図 1）を実現しており，夜間および休日の宿 直業務の省力化 (中央集中監視), 営業所間の系統融通が 容易になっている。なお，四電の配電線路こう長は

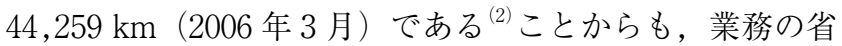
力化は重要である。

また, 阪神淡路大震災（1995 年 1 月 17 日）の教訓 ${ }^{(3)}$ か ら，耐震対策を施すことにより，システム全体の信頼性向
上も図っている。なお，文献(3)によれば，主要電力設備 に扔いて，配電設備の被害数が最多と報告されている。

本稿では，見学の機会をいただいた四電・宇和島支店 （愛媛県宇和島市）に新たに導入された配電自動化システ ムとその震災対策を紹介するとともに，古くて新しい (?)需要開拓の試みである「南予の古民家再生プロジェ クト」について紹介する。

\section{2. 新配電自動化システム}

\section{1 システム概要}

宇和島支店では県都外支店・新配電自動化システムの運 用を 2007 年 4 月から開始している。同システムを図 2 に 示す。同システムはワークステーションとパソコンによる クライアント・サーバ方式となっており，監視制御サーバ にUNIX マシン（図 3）を，配電線操作卓（クライアント 操作卓) にWindows パソコン（図 4) を採用している。監 視制御サーバは耐震対策として, サーバ設置ラックの脚部 が球体で支持されており, 黄色で塗られた範囲が可動範囲 となっている。

図 4 の左側のモニ夕には作業操作実施手順が表示されて

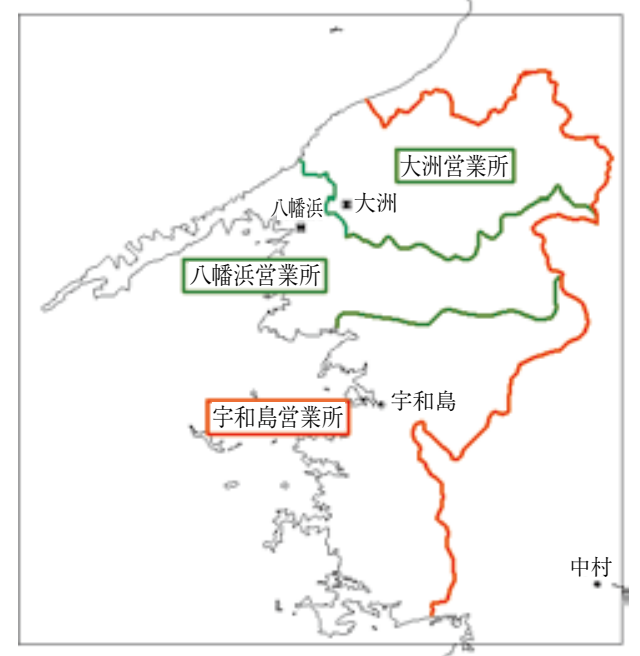

図 1 宇和島支店区域図（宇和島営業部，大洲，八幡浜営業所） (出典 : 四国電力配電部) 


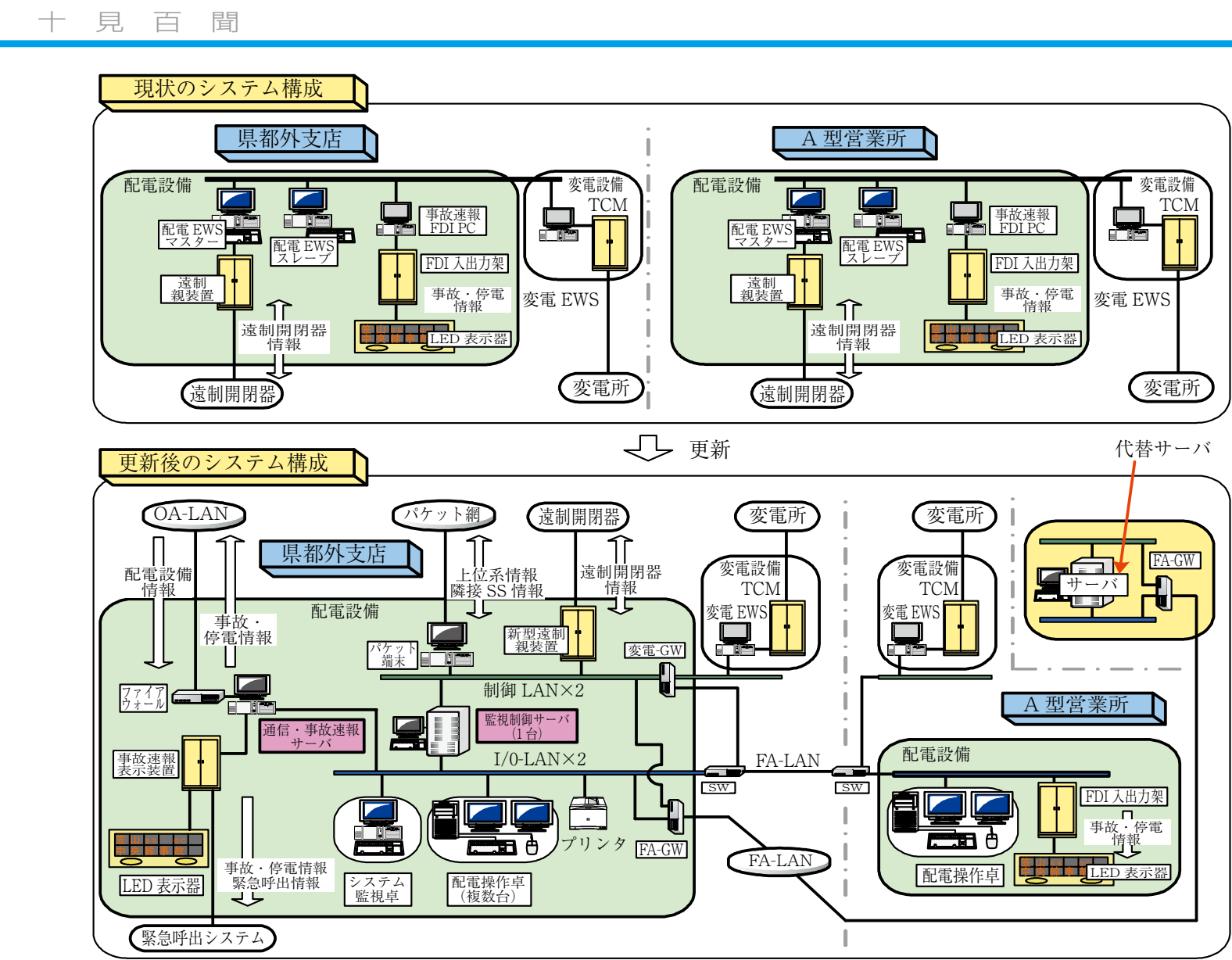

図 2 県都外支店・新配電自動化システム構成概要図

(出典：四国電力県都外支店・新配電自動化システム)

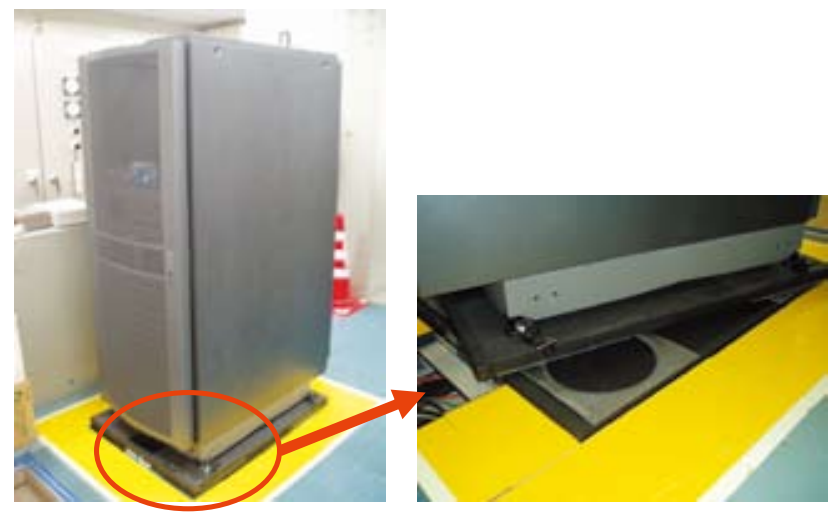

図 3 監視制御サーバの耐震対策

おり，いつ，どこでどのような操作を実施したか，また， 今後の作業予定等も表示される。右側のモニ夕には配電線 系統図が表示されており，視覚的に事故箇所を特定でき る。

\section{2 バックアップシステム}

同システムでは監視制御サーバを 1 台運用としており， 別所に設置した代替サーバと FA-LAN（Factory Automation-Local Area Network) 連係により接続可能としてい る。この連係により, 代替サーバのシミュレーション機能

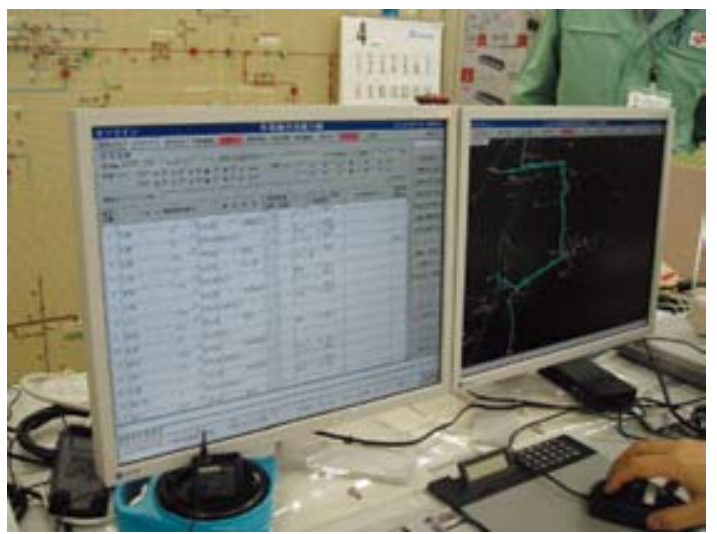

図 4 配電線操作卓

を利用した操作員教育が実施できるとともに，監視制御サ ーバが故障した場合に，この代替サーバを利用した緊急運 転が可能であり，信頼性を確保している。なお，代替サー バは用途が限定されていることから，5県都外支店システ ムで 1 台を共有する予定である。

\section{3 情報連係用装置の統合}

県都支店システムでは，事故・停電情報を通知・表示さ せる「事故速報サーバ」と, 本店ホストから配電設備情報 を取得し, 事故・停電情報を他システムへ連係させる「通 
信サーバ」がそれぞれ設置されている。県都外支店システ ムでは, 汎用計算機の処理能力が向上したことから, 上記 の機能を統合して「通信・事故速報サーバ」を 1 台のみ設 置している。

\section{4 制御権切替機能}

営業所にはFA-LAN で連係した配電操作卓を支店と同 様に設置しており，図５に示す「制御権切替ボタン」によ り制御権を取得することで, 取得エリアの变配監視・制御 ができる。また，他所の変配監視・制御状態を把握できる ように「表示ランプ」を設けている。配電系統の保安確保 のため，同一エリアを複数事業所から同時に制御できない ように,「制御権切替ボタン」には排他機能を設けてい る。ただし, 南海地震等の大規模災害時の相互応援が必要 な場合には，「制御権解除ボタン」で排他機能を解除する ことにより，迅速な対応が可能となる。

\section{5 効 果}

営業所における休日, 夜間の変配業務を拠点事業所へ集 中化する運用や，大規模災害時の事業所間応援等が可能と なり，変配業務の効率化を実現している。また，監視制御 サーバの 1 台運用や情報連係装置の統合等により，システ ムの省スペース化とコストの大幅低減を実現している。

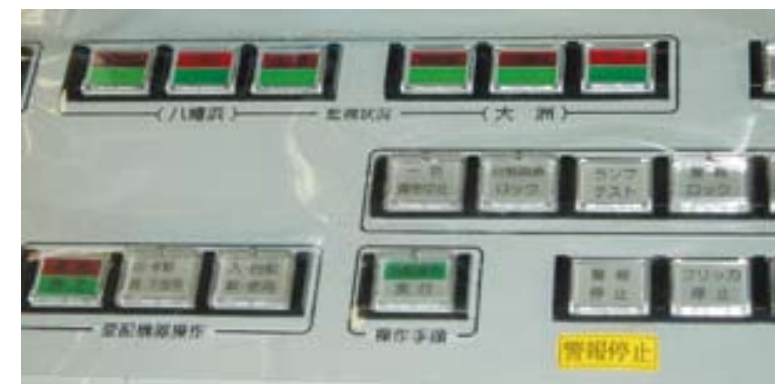

図 5 制御権切替ボタン

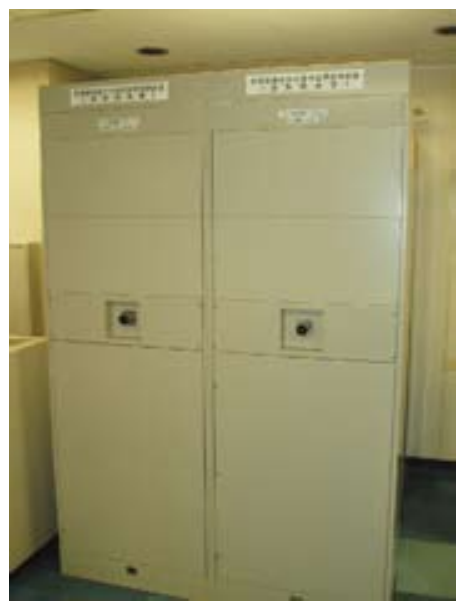

図 6 配電線搬送方式遠方監視制御装置 (親装置)

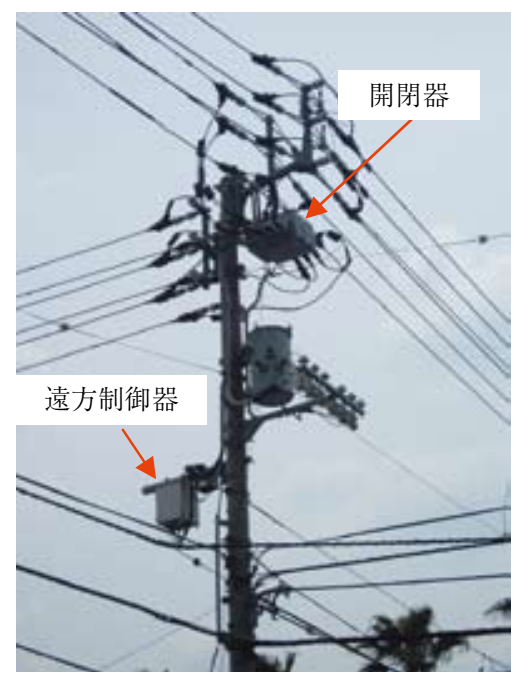

図 7 遠方制御器 (子装置)

\section{3. 遠方監視制御装置}

配電自動化システムの更新に併せて，自動開閉器を制御 する遠方監視制御装置も取り替えている。図 6 に配電線搬 送方式遠方監視制御装置（親装置, 宇和島支店建屋内), 図 7 に柱上の遠方制御器 (子装置), 図 8 に中継装置 (変 電所内装置), 図 9 に搬送結合器 (変電所内装置) を示 す。

\section{4. 変電所の浸水対策}

四電では東南海・南海地震の同時発生を想定（マグニチ ユード 8.6) し，シミュレーション結果をもとに津波による 浸水対策を進めている ${ }^{(4)}$ 。キュービクル浸水が予想される 変電所に対しては, 浸水レベルに応じた翯上げ（図 10）や, 変電所内の建屋に遮水屝設置 (図 11) などを実施している。

\section{5. 南予の古民家再生プロジェクト}

愛媛県南予地域には，日本の伝統や地域の歴史を伝える 古民家が多数残されており，この古民家を電化リフォーム する「南予の古民家再生プロジェクト」が四電・宇和島支 店と南予地域の工務店・設計事務所 72 社で 2006 年 2 月か ら進められている (図 12) ${ }^{(5)}$ 。電化住宅の新たな普及拡大 策として成果を上げており, 愛媛県「移住促進型観光推進 事業」の「移住体験モニターツアー」との連携が実現する など, 新たな地域経済活性化策として注目を集めている ${ }^{(6)}$ 。

\section{6. おわりに}

配電系統の監視制御 - 運用に情報通信技術が必要不可欠 であることを，本見学により認識できた。著者が所属する 大学では, 異なる講座が電力分野と情報通信分野の教育を 


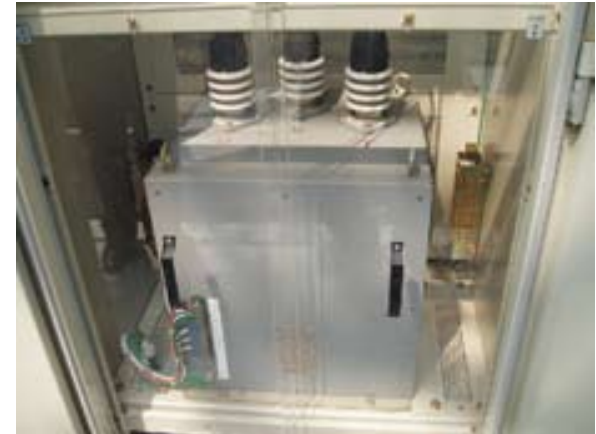

図 9 搬送結合器

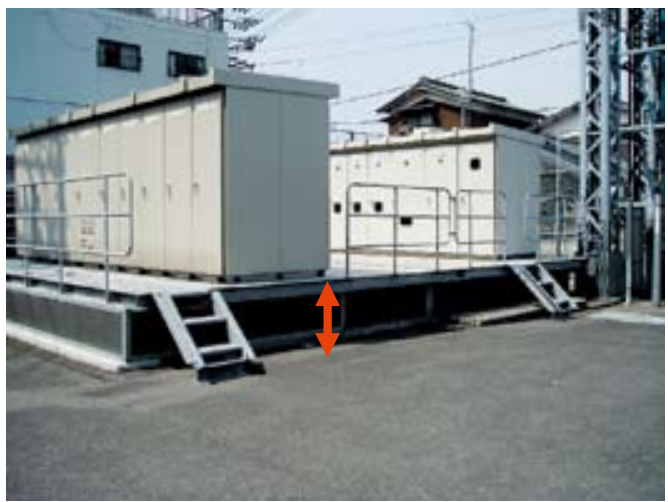

図 10 変電所電気設備の嵩上げ

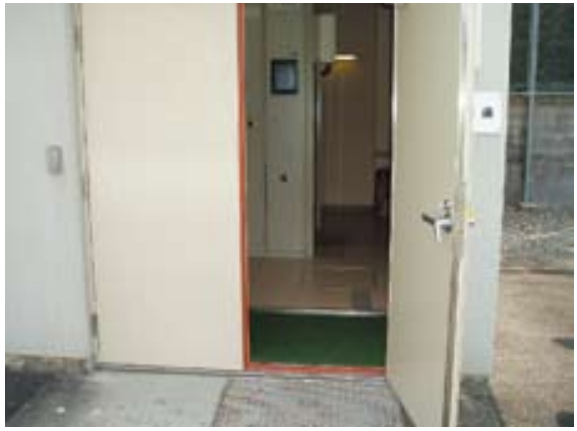

図 11 変電所建屋の遮水対策（遮水扉）

担当しており，学生も両分野はあまり関係が無いと考えて いるようである（学生会員の皆さんいかがでしょう か?）。しかしながら，電力系統の監視制御・運用は情報 通信技術に支えられており，両分野の融合的教育が必要で あると再認識した。

震災対策は公共事業者にとって重要な課題であり，具体 的な対策事例を見学できたことは有意義であった。

新たな需要開拓として, 古民家に着目した点は興味深く, 愛媛県南予地域だけではなく全国的にこのような取り組み が展開できれば，地方経済活性化に繋がると考えられる。

最後に，取材のために貴重なお時間を賜り，丁寧なご説 明をいただきました宇和島支店 副支店長 兼 営業部長 · 馬場様, 同支店 配電センター長・栘田様, 配電センター 副長 ·池田様, 配電センター 主任 ·伊藤様, 同主任 · 門

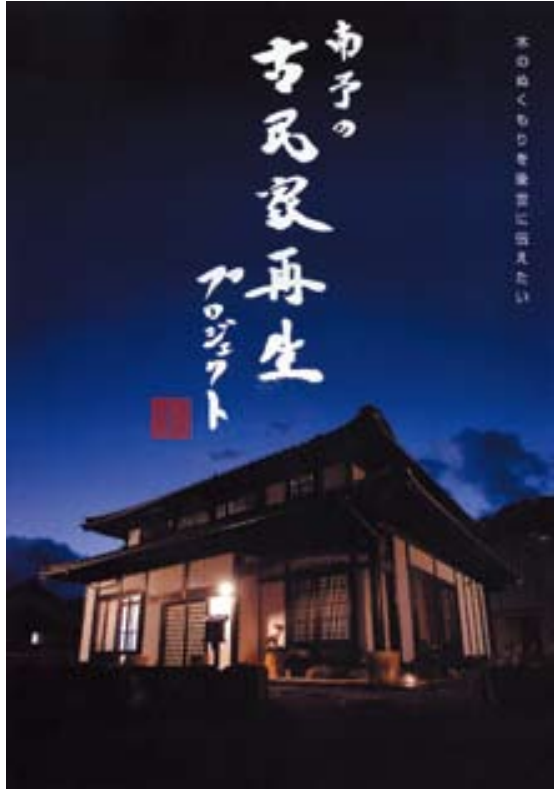

図 12 南予の古民家再生プロジェクト (出典 : 四国電力宇和島支店パンフレット)

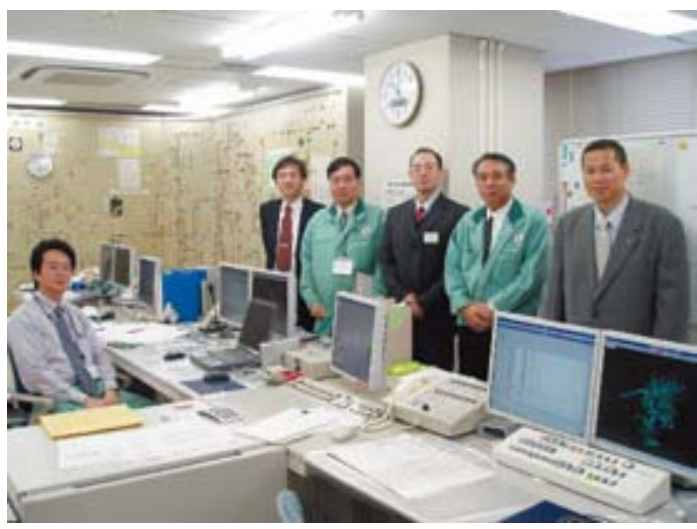

図 13 配電操作卓前での集合写真（左から伊藤主任，正木部 長，池田副長，川田，栘田センター長，野々村本店配 電部副リーダー)

田様, 本店配電部 副リーダー・野々村様, そして, 本取 材のお世話をいただきました(株)四国総合研究所 電力技術 部部長・正木様に御礼申し上げます。

取材 / 川田昌武（徳島大学）〈文〉,

文 献

（1）道上勉：「改訂版 送電・配電」, 電気学会 $(2001)$

(2) 四国電力の概要 HP:http://www.yonden.co.jp/yonden/page_01 html

（3）白田修:「電力設備の応急対応から耐震性評価まで（特集 阪神. 淡路大震災の教訓を生かす $2 」$, 電学誌， 116, 2, pp.73-75（1996

（4）四国電力・東南海・南海地震に対する当社の対策 HP: http://www.yonden.co.jp/press/re0409/j0ypr007.htm http://www.yonden.co.jp/press/re0603/j0ypr008.htm

（５）南予の古民家再生プロジェクト HP:http://www.ko-minka.jp/

（6）電気新聞 2007 年 1 月 26 日 11 面（古民家の電化 地域を活性 化) 